in Berkeley with a strength of several hundred millicuries using the ordinary technique of bombardment with deutrons in the target chamber; radioactive sodium, in the process of decaying to magnesium in the ground state, emits a gamma-ray of such energy as may dispose of the need for radium for some purposes. This, with the results of the investigations into the yields using internal targets, and the possibilities of neutron irradiation of malignant tissue, should be an added stimulus to those who are in favour of the immediate construction of a cyclotron for medical purposes in Great Britain, believing that active research alone, with the most recent techniques available, is the necessary preliminary to any further progress in the treatment of cancer.

There are now some twenty-six cyclotrons, either operating or under construction, in various parts of the world. At Berkeley there are two cyclotrons, one belonging to each of these two eategories. In addition, cyclotrons are running, or have been running, at the following places: Ann Arbor, Michigan; Cambridge ; Copenhagen ; Ithaca, New York (Cornell) ; Leningrad ; Princeton; New York (Columbia); Rochester, New York; Swarthmore, Pennsylvania (The Bartol Foundation of the Franklin Institute); Tokyo; Urbana, Illinois.

Cyclotrons are also under construction at Birmingham ; Bloomington, Indiana ; Cambridge, Massachusets (Harvard University and Massachusets Institute of Technology); Chicago ; Columbus, Ohio ; Lafayette, Indiana (Purdue); Liverpool ; Montreal (McGill); New Haven, Connecticut (Yale) ; Paris ; Seattle, Washington ; Stockholm.

The conclusion of this article on the cyclotron would, indeed, be inappropriate without a tribute to Prof. Ernest Lawrence, through whose imagination and experimental skill this valuable tool has been placed in the hands of the experimental physicist.

\title{
North Rona: a North Atlantic Island*
}

\section{By Dr. F. Fraser Darling}

$\mathrm{M}^{\wedge}$ AN has such little interest in Rona that this island of less than half a square mile has disappeared from many maps of Scotland. It lies about forty-five miles north-east of the Butt of Lewis and north-west of Cape Wrath. The island is completely rockbound, the cliffs varying from a few feet to 355 feet in height. The continual Atlantic swell makes landing difficult and often impossible.

Rona is a northern outpost of the Hebridean hornblende gneiss intersected by several veins of pegmatite. Botanically, the island is distinct from the Hebrides. The northern end of Lewis is a vast peat bog which grows a characteristic herbage complex dominated by heather (Calluna). But there is no peat on Rona. The rock is covered with a thin layer of soil held together with a good turf of Yorkshire fog (Holcus), bents (Agrostis), sheeps' fescue (Festuca). Sedges (Carex) are rare on Rona, occurring only to the west of the ancient village site, where the turf has been cut for fuel hundreds of years ago. There are no permanent pools of fresh water on Rona. A well for seepage has been chiselled in the solid rock at the edge of the cliff in Poll Heallair on the south side of the island and it holds about ten gallons.

\footnotetext{
* Substance of a Friday evening discourse delivered at the Royal Institution on January 20.
}

The drier rocky places are covered with a wealth of sea pink (Statice) and buckshorn plantain (Plantago); the cliff edges, heavily manured by the summer population of birds, grow luxuriant sprays of scurvy grass (Cochlearia), some sheep sorrel (Rumex) and mayweed (Matricaria). The village area with its lazy beds grows wild white clover (Trifolium) on the dry banks of conserved soil, and in the immediate vicinity of the ancient dwellings, silverweed (Potentilla) almost crowds out everything else. There is no bracken, fern or spleenwort, and few of those flowers which make the northern lands gay in May and June.

The whole of Rona is washed by salt spray in winter gales, but the northern peninsula of Fianuis is often impassable under a continuous driven cloud. Only plants with a high tolerance of salt can grow there-annual poa grass (Poa), sea pink, sea milkwort (Glaux) and chickweed (Cerastium).

So far as we know, St. Ronan was the first human inhabitant of Rona, in the eighth century A.D. He moved to Rona from Eoropaidh at the north end of Lewis and adopted the name of the island as his own. Thus we gather that Rona, ron-y, has been the island of seals for a very long period. The cell of St. Ronan still remains in a fair state of preservation, and I have done some 


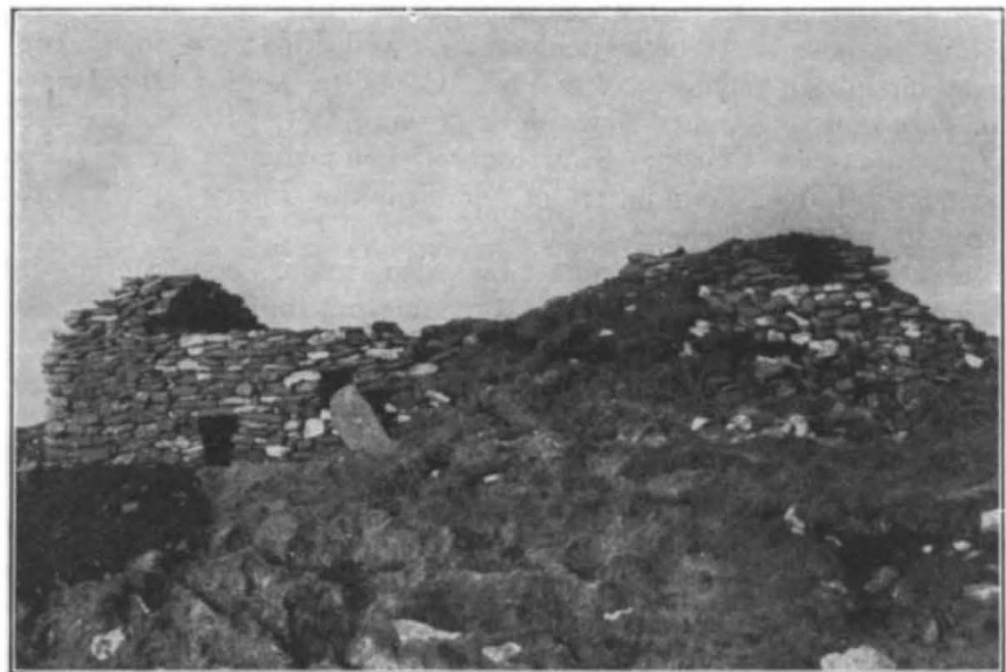

Frg. 1. Chapel (left) and Cell of St. Ronan (right) showing RESTORATION OF SOUTH WALL.

with food and raiment; though at the same time they are very precise in the matter of property among themselves ; . . . they take their surnames from the colour of the sky, rain-bow and clouds". A plague of rats came ashore from a wrecked ship between 1680 and 1690 and ate up the whole sustenance of the people, who then starved to death. The half-underground dwellings remain and it is evident they were entered by low and devious passages which would baffle the wind, which is an all-important factor in life on Rona. Several quern stones were found about these dwellings and two fragments of stone vessels.

Rona is an important sea-

excavation and slight restoration (Fig. 1). The east and west walls of the cell inside are almost perpendicular, but the longer north and south walls slope inwards rapidly, and at a height of more than $11 \mathrm{ft}$. are $18 \mathrm{in}$. apart. Rectangular slabs of gneiss are placed across the top to finish the roof. The length and breadth of the cell at floor-level are $11 \mathrm{ft} .6 \mathrm{in}$. and $8 \mathrm{ft}$. Earth and stones were banked high round the outside of the north, east and south walls so that the building was practically underground.

The outside west wall became the east inside wall of a chapel which was built some time after Ronan's cell. This building, also in dry-stone but of poorer workmanship, is $14 \mathrm{ft} .8 \mathrm{in}$. by $8 \mathrm{ft} .3 \mathrm{in}$. and forms in effect a nave to the cell as chancel, though it is doubtful whether the two buildings were used conjointly as such. A block of masonry was laid bare on each side of the doorway into the cell and at the foot of these piers, which were taken to be the supports for the wooden altar in the later chapel (described by Martin Martin in 1703), a rough paving was found leading into the cell. The paving of the cell has been completely cleared at the eastern end, revealing an altar of wellbuilt masonry $2 \mathrm{ft}$. $6 \mathrm{in}$. high, $3 \mathrm{ft}$. broad and $2 \mathrm{ft} .3 \mathrm{in}$. deep. A polished stone, rather smaller than a man's fist, was found at the foot of this altar and it appears to be of the same rock as Iona green marble, a rock entirely foreign to North Rona.

The first written mention of Rona and its people was made in 1549 by Sir Donald Monro, High Dean of the Isles, and later we read from Martin Martin of the life of the five families: "They covet no wealth, being fully content and satisfied bird station. The guillemot population is approximately 12,500 pairs; kittiwakes are equally numerous and the puffins are countless. There

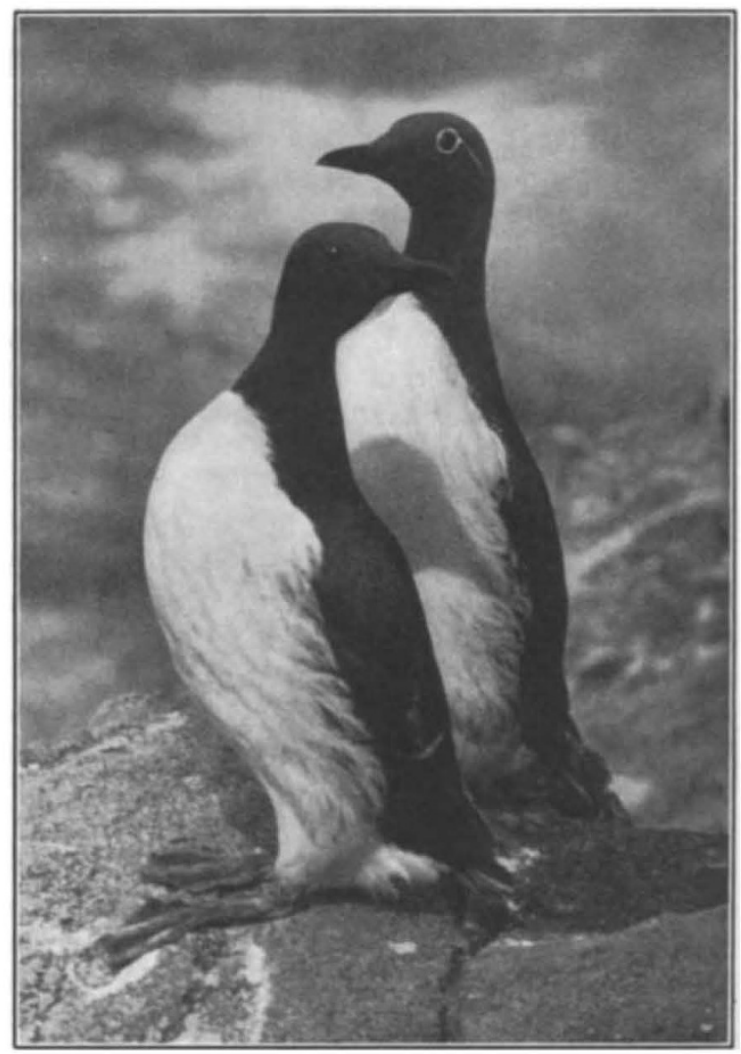

Fig. 2.

BRIdLed GUILlemot with PLAIN Mate. $13 \cdot 2$ per cent of common guillemots on North Rona are bridled. 
are about 750 pairs of razorbills and 600 pairs of fulmar petrels. A population of at least 500 pairs of great black-backed gulls is predatory on the puffins. Storm petrels are numerous, and Rona is one of the three British breeding stations of Leach's fork-tailed petrels. Arctic terns and black guillemots also breed on the island. There is a resident flock of $300-400$ starlings. Many interesting migrants visit Rona on their spring and autumn passage-flocks of white wagtails, of waders such as knots, sanderlings, dunlins and redshanks. Turnstones may be resident. There are such occasional visitors as the corn is now largely fed to the cattle in the straw.

The annual association of the seals with the land for reproductive purposes is their time of greatest danger, and the social system of the animals has become finely adapted for lessening this danger of the sea's edge. The seals are migrating to the island throughout August, but on arrival they do not come farther ashore than outlying skerries and ledges at the foot of the cliffs. Behaviour alters early in September, when mature bulls come on to the main mass of the island, as far as 300 yards inland, and lie quiet and alone

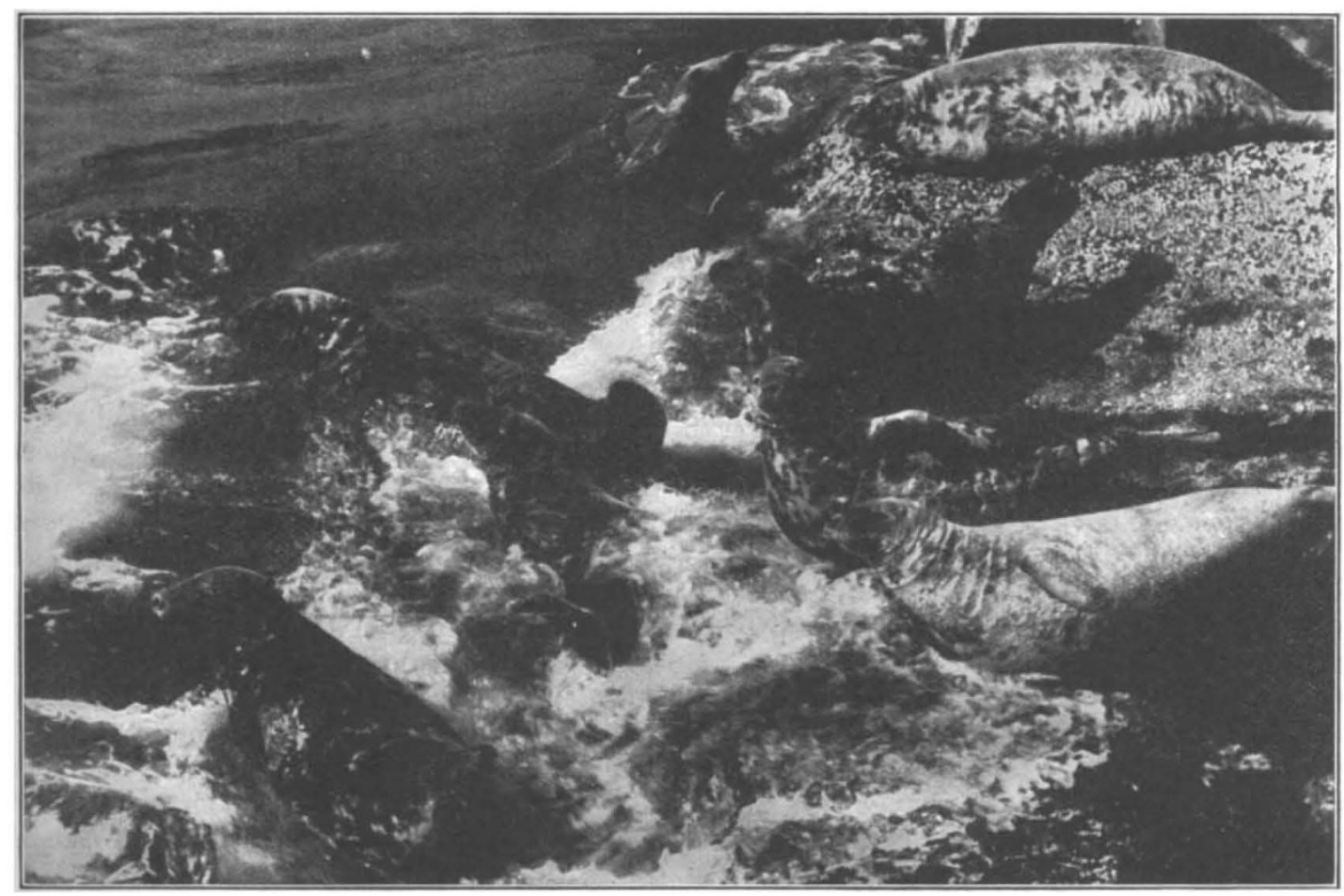

Fig. 3.

Atlantic grey seals on A ledge at the Edge of the surf.

green sandpiper, spotted redshank, short-eared owl, buzzard, hen harrier, woodcock and great snipe. Although the island has a good turf, neither grey lag nor barnacle geese winter there.

North Rona is the headquarters of the Atlantic grey seal, Halichoerus gryphus (Fig. 3). Protection by law has helped the species to recover from the low numbers brought about by the careless hunting in the nineteenth century. There is also the fact that the advent of rubber for sea boots and paraffin for light have made it unnecessary for the Hebridean to use sealskin and blubber. Crofters' cattle are now better fed, and no longer receive seal oil in the winter since threshing of the peoples' own oats has declined and the by small pools of brackish water. Bulls in adjacent territories make no attempt to impinge on each other's ground, but throughout the breeding season there is a traffic of bulls coming up from a neutral reservoir at the sea's edge, and these challenge the bulls in possession. The winner stays and the loser returns to the neutral ground, where all challenging behaviour is laid aside.

Cows come ashore about a week later than the bulls and, by the cows' freedom to move where they will, it appears that the territories of the bulls are most decidedly entities of space and not of numbers of cows within that space. The matings take place 11-14 days after the birth of the calves, so the bulls have been ashore then at least three 
weeks without any cows having been in season. The maiden cows and a few old cows without calves collect on the surf-ringed skerry of Loba Sgeir and mate there with young bulls. It was exceptionally interesting to observe that all these animals lay cheek by jowl without any apparent expression of territorial behaviour. The young stock does not come inland.

After the breeding season a large proportion of the adult stock gathered on Loba Sgeir and lay quiet there until they had moulted their coats. They leave Rona then to feed about the Hebridean coasts until the next season.

The Atlantic grey seal calf is thin when born but puts on fat at a very rapid rate. Its fluffy white coat begins to be shed at a fortnight old and it is then that lactation in the cow rapidly declines and maternal care ceases. The calves face starvation until they reach the sea, and from a cliff-bound island that journey is a perilous one.

The occupation of the northern peninsula of Rona by the seals affects the vegetative complex and creates a favourable environment for Chironomid larvæ. Thus the island is a fruitful port of call for migrant birds and a place of immense consequence to many others. In any attempt to conserve our country's wild life we should not forget the little islands, for they have a value as sanctuaries far beyond that which their size would indicate. Rona, where man has failed to survive, is one of the great cities of this earth.

\section{Scientific Approach to Milk Policy}

$\mathrm{M}^{\mathrm{A}}$ ANY members of the British Association for the Advancement of Science have been feeling during the past three or four years that more efficient machinery should be devised by the Association for the consideration of the effects on society of scientific developments and discoveries, and for the application of scientific methods to social ends. At the Cambridge meeting of the Association in August last, it was decided to constitute a new Division of the Association to be concerned with social and international relations of science, and Sir Richard Gregory was elected the first chairman. It was later decided that the Division should hold meetings, at times intermediate between those of the normal annual meetings of the Association, at different centres in Great Britain and elsewhere.

The Nutrition Sub-Committee of the new Division has been the first to get off the mark, and, at the University of Reading on March 28, held a one-day conference on milk, in its nutritional and allied aspects. It is a commonplace that the handling of the milk question is the most awkward problem in any long-range policy concerned with improvement either in general health or in agriculture, and the boldness of the young Division in firmly grasping this important domestic nettle at its first meeting is a good augury for its future activities. In view of the trying weather, the attendance (about 180 were present at the main session) cannot be regarded as other than satisfactory.

The day began with a visit of the more weatherresistant members to the National Institute for Research in Dairying at Shinfield near Reading.
Here the party was shown, by the Director and staff, experimental work on various ad hoc dairy industry questions, and also on some of the more fundamental problems of dairy science. Amongst the investigations described were those on the protein requirements of dairy cattle, on new methods for the pasteurization of milk, on the effect of various types of commercial processing on the nutritive value of milk, on the causes of low compositional quality in milk, and on the hormonal control of lactation. The new chemical and physiological laboratories now rapidly approaching completion, and the completely rebuilt dairy machinery testing centre were inspected, and the memorial library and the recently founded Imperial Bureau of Dairy Science visited.

After lunching at the University, members met for the afternoon session in the Great Hall, where the Vice-Chancellor (Sir Franklin Sibly) welcomed the Association on behalf of the University. The chair was taken by Sir Richard Gregory, who introduced the three principal speakers, Dr. Harriette Chick, Prof. J. C. Drummond and Dr. A. W. Scott. The papers given by these three dove-tailed so closely into one another that it is more convenient in this brief report to deal with them together.

The factual basis for the emphasis which has been laid on the importance of milk in the national dietary was re-described, and the food value of milk products, for example skim milk, was discussed. Despite its food value, milk is rather an awkward material to handle and distribute, and a potentially dangerous material for the consumer if it is not properly produced and processed. Whilst Great 